\title{
MENCIPTAKAN PENGELOLAAN ARSIP SURAT KABAR \\ YANG ANDAL \\ (STUDI KASUS DEPO ARSIP SUARA MERDEKA)
}

\author{
Joseph Army Sadhyoko ${ }^{l}$
}

\begin{abstract}
Abstrak
Depo Arsip Suara Merdeka menciptakan pengelolaan arsip surat kabar yang andal. Pengelolaan tersebut diwujudkan dalam program mesin pencari data yang telah disusun secara sistematis. Pengelola berharap pengguna arsip dapat lebih efektifmengakses arsip surat kabar Suara Merdeka dengan media tersebut.
\end{abstract}

Kata Kunci: pengelolaan arsip yang andal, mesin pencari data, efektivitas akses

\section{PENDAHULUAN}

Yoshi Fajar Kresno Murti pernah melontarkan dua buah problematika kerja arsip dan pengarsipan seni budaya di Indonesia yang selalu dimaknai oleh pemerintah sebagai perkara politic of claim dan politic of access. Pada problem pertama, politic of claim menekankan motif pendokumentasian selalu didasari oleh pemahaman bahwa arsip diperlukan untuk menjaga "keunikan" aset seni budaya bangsa. Sementara itu, pada problem kedua, politic of access menjadi sangat penting untuk menjaga akses otoritas (identitas atau lokalitas) yang dibayangkan oleh nalar pemerintah mempunyai keunikan atau bersifat tiada duanya (adiluhung). Kedua problem tersebut dianggap oleh Yoshi dan kawan-kawan sesama pegiat kearsipan budaya di Indonesia, sebagai bentuk legitimasi pemerintah yang gagal dipraktikan $^{2}$. Kegagalan ini tentunya diharapkan tidak akan

\footnotetext{
1 Staf Pusat Data Redaksi Suara Merdeka

${ }^{2}$ Yoshi Fajar Kresno Murti, "Daur Ulang!: Kerja Arsip dan Pengarsipan Seni Budaya di Indonesia", dalam Farah Wardani dan Yoshi Fajar Kresno Murti (ed.), Arsipelago: Kerja Arsip dan Pengarsipan Seni Budaya di Indonesia Edisi 1 (Yogyakarta: Indonesian Visual Art Archive (IVAA), 2014), hlm. iv-v.
} 
menular pada kerja arsip di bidang lainnya. Kerja arsip harus terus berjalan sesuai yang diamanatkan Undang-Undang Nomor 43 Tahun 2009 tentang Kearsipan.

Berdasarkan undangundang kearsipan tersebut, arsip secara luas dipahami sebagai rekaman kegiatan atau peristiwa dalam berbagai bentuk dan media sesuai dengan perkembangan teknologi informasi dan komunikasi yang dibuat dan diterima oleh lembaga negara, pemerintahan daerah, lembaga pendidikan, perusahaan, organisasi politik, organisasi kemasyarakatan, dan perseorangan dalam pelaksanaan kehidupan bermasyarakat, berbangsa, dan bernegara ${ }^{3}$. Arsip budaya merupakan salah satu bagian dari pengertian ini yang secara khusus merekam kegiatan yang berhubungan dengan kebudayaan dalam media tertentu. Dalam karya tulis ilmiah ini, penulis memilih pembahasan khusus pada arsip media massa yang dalam bentuk surat kabar atau koran.

Surat kabar atau koran memiliki pengertian, yaitu lembaran-lembaran kertas bertuliskan kabar (berita) dan sebagainya, terbagi dalam kolom-kolom (8-9 kolom), terbit setiap hari atau secara periodik ${ }^{4}$. Penerbitan yang periodik dan memuat kabar-kabar yang dicatat secara aktual sesuai dengan peristiwa yang terjadi sezaman, menjadikan kerja pengarsipan surat kabar memiliki peran yang vital. Sartono Kartodirdjo mendukung peran vital dari surat kabar sebagai salah satu bahan dokumenter. Menurut Sartono ada empat jenis bahan dokumenter, yaitu otobiografi, surat kabar, dokumen-dokumen pemerintah, dan cerita roman. Keempat jenis bahan dokumenter ini sangat penting bagi ilmu sejarah secara khusus dan perkembangan ilmu pengetahuan lainnya secara

${ }^{3}$ Arsip Nasional Republik Indonesia, Undang-Undang Republik Indonesia Nomor 43 Tahun 2009 tentang Kearsipan (Jakarta: Arsip Nasional Republik Indonesia, tanpa tahun), hlm. 3.

${ }^{4}$ Departemen Pendidikan dan Kebudayaan, Kamus Besar Bahasa Indonesia Edisi Kedua (Jakarta: Balai Pustaka, 1999), hlm. 525. 
umum.

Sejak abad 19 surat kabar sudah digunakan sebagai bahan dokumenter yang berharga. Ruang lingkupnya sangat luas meliputi soal-soal lokal sampai internasional. Segi substantifnya mencakup berbagai segi kehidupan sosial, meskipun pada umumnya segi politik yang diutamakan. Fokus perhatiannya juga meliputi berbagai golongan usia dan sebenarnya disesuaikan dengan perhatian publik yang sangat heterogen. Keuntungan dari berita-berita yang dimuat di surat kabar adalah seringnya surat kabar memuat informasi yang tidak akan pernah dicantumkan dalam salah satu dokumen pemerintah dan informasinya memuat faktafakta berita yang berjarak sangat pendek dengan waktu terjadinya peristiwa, sehingga pada umumnya tepat ${ }^{5}$.

Suara Merdeka sebagai salah satu media massa lokal terbesar di Indonesia sangat menyadari pentingnya pengelolaan arsip surat kabarnya. Secara khusus sejak 2003 pihak manajemen redaksi membangun Depo Arsip Suara Merdeka untuk mewadahi penyimpanan dan pengelolaan arsip koran Suara Merdeka. Dengan jargon dari Budi Santoso, pemilik perusahaan ini yang terpajang di salah satu dinding kantor Depo Arsip yang bertuliskan "Berkembang Sekarang untuk Bertahan Esok", Suara Merdeka ingin secara tulus dan ikhlas menyumbangkan yang dimiliki untuk $\mathrm{p}$ e r k e m b a n g n i $1 \mathrm{~m} \mathrm{u}$ pengetahuan yang termuat dalam setiap pemberitaannya. Jargon ini penulis intepretasikan sebagai sebuah proses pengelolaan arsip yang harus mengikuti perkembangan teknologi media massa pada masa kini. Tujuan jangka panjang Depo Arsip Suara Merdeka adalah bisa terus

${ }^{5}$ Sartono Kartodirdjo, Pemikiran dan Perkembangan Historiografi Indonesia: Suatu Alternatif (Jakarta: PT Gramedia, 1982), hlm. 108-109. 
bertahan dalam memberikan pelayanan kepada para pengguna arsip koran Suara Merdeka.

Ahmad Zaini Bisri, salah satu redaktur senior Suara Merdeka, pernah menulis sebuah artikel mengenai Depo Arsip Suara Merdeka dan kerja arsip yang diadakan di dalamnya. Ia memberikan julukan tempat ini sebagai "gudang arsip yang tak ternilai harganya yang memuat harta karun". "Harta karun" itu berupa kumpulan fakta, pendapat, kejadian baik secara naratif maupun piktografis (gambar) di berbagai daerah di Jawa Tengah sejak 11 Februari 1950 hingga sekarang, dan isuisu nasional dan internasional yang penting juga tidak ketinggalan. Semua "harta karun" tersebut sebagian besar sudah diubah dalam bentuk digital, sehingga bisa dilihat di monitor komputer ${ }^{6}$.

Semua kondisi yang telah dijabarkan di atas menjadikan para pengelola Depo Arsip Suara Merdeka terus berjuang untuk mewujudkan pengelolaan arsip yang andal. Lalu, bagaimana, apa bentuk, dan apa tujuan pengelolaan arsip yang andal tersebut? Tiga pertanyaan tersebut menjadi pertanyaan permasalahan yang akan diuraikan dalam karya tulis ilmiah ini.

\section{KERANGKA TEORI}

Pengelolaan arsip yang andal merupakan sebuah konsep yang telah disepakati dalam Undang-Undang Kearsipan Nomor 43 Tahun 2009 pada penjelasan Pasal 3 huruf c yang berkenaan dengan tujuan penyelenggaraan kearsipan. Menurut penjelasan tersebut, pengelolaan arsip dilaksanakan berdasarkan sistem yang mampu menampung dan merespon kebutuhan perkembangan zaman. Sistem pengelolaan arsip yang andal memiliki kemampuan untuk menjaring atau menangkap (capture) semua arsip dari seluruh kegiatan yang dihasilkan organisasi; menata

\footnotetext{
${ }^{6}$ Ahmad Zaini Bisri, "Dari Konsekstasi hingga Tema Politik Lokal: SM Jadi Jujugan Peneliti Mancanegara", Suara Merdeka, 11 Februari 2014, hlm. 1 dan 11.
} 
arsip dengan cara yang mencerminkan proses kegiatan organisasi; melindungi arsip dari pengubahan, pengurangan, penambahan, atau penyusutan oleh pihak yang tidak berwenang; menjadi sumber utama informasi yang secara rutin mengenai kegiatan yang terekam dalam arsip; dan menyediakan akses terhadap semua arsip berikut beserta metadatanya ${ }^{7}$.

Konsep pengelolaan arsip yang andal ini harus mampu bertahan dalam tiga situasi umum yang terjadi secara bertahap di setiap lembagalembaga pengelola arsip, baik milik pemerintah maupun swasta. Tiga situasi umum dalam pengelolaan arsip menurut Joned Suryatmoko, yaitu situasi riil, situasi transisi, dan situasi ideal. Pertama, situasi riil adalah situasi yang menempatkan pengelolaan arsip yang tersimpan tidak cukup diketahui dan diakses oleh khalayak umum. Situasi ini adalah situasi pertama dan yang paling dasar terjadi di semua lembaga-lembaga pengelolaan arsip. Kedua, situasi transisi adalah situasi pengembangan yang masih membutuhkan proses yang terus menerus dilakukan untuk mencapai kondisi pelayanan arsip yang ideal. Pada situasi kedua ini, hampir semua lembaga-lembaga kearsipan yang mendapatkan dukungan sumber daya manusia dan teknologi informasi sedang berproses di situasi ini. Ketiga, situasi ideal adalah situasi sempurna yang menempatkan arsip yang tersimpan dapat diketahui dan diakses oleh khalayak. Dengan begitu, arsip menjadi bermakna karena ia dibaca dan dijadikan rujukan dalam berbagai bidang keilmuan ${ }^{8}$.

Dengan melihat kondisikondisi yang dialami saat ini, seyogyanya lembaga kearsipan tidak hanya membiarkan arsipnya telanjang begitu saja

${ }^{7}$ Arsip Nasional Republik Indonesia, Undang-Undang Republik Indonesia Nomor 43 Tahun 2009 tentang Kearsipan (Jakarta: Arsip Nasional Republik Indonesia, tanpa tahun), hlm. 62-63. Joned Suryatmoko, "Arsip Bergerak: Mengarsipkan Seni Tradisi, Mengolah Interaksi", dalam Farah Wardani dan Yoshi Fajar Kresno Murti (ed.), Arsipelago: Kerja Arsip dan Pengarsipan Seni Budaya di Indonesia Edisi 1 (Yogyakarta: Indonesian Visual Art Archive (IVAA), 2014), hlm. 140. 
dan berharap khalayak mengaksesnya. Lembaga kearsipan perlu membuatkan program yang mampu mewadahi bentuk olahan arsip dapat diakses dalam format atau cara lain. Dengan demikian, masyarakat akan mempunyai lebih banyak pilihan dalam mengakses tawaran lembaga-lembaga arsip tersebut. Oleh sebab itu, pemanfaatan teknologi informasi dalam pengelolaan arsip yang andal sangat diperlukan, khususnya dengan menggunakan media komputer yang mampu mewadahi proses digitalisasi arsip.

\section{ANALISIS}

Proses digitalisasi arsip di Depo Arsip Suara Merdeka sudah berlangsung sejak 1996 ketika masih menjadi satu dengan redaksi di Kantor Harian Suara Merdeka Jalan Kaligawe km. 5 Semarang. Proses tersebut berlangsung hingga Depo Arsip Suara Merdeka berdiri sendiri dengan menempati kantor redaksi lama di Jalan Merak 11 A Semarang pada tahun 2003. Tidak hanya pada tahun 2003 saja proses ini berlangsung, tetapi terus dilakukan hingga saat ini.

Koleksi koran Suara Merdeka dimulai sejak 11 Februari 1950 dan proses digitalisasi ditargetkan selesai pada 31 Desember 2001. Sampai saat ini proses tersebut sampai di koleksi Oktober 1998. Pada tahun 2002, koran Suara Merdeka sudah ada yang berbentuk $p d f$. Sementara itu, untuk semua koran yang sudah didigitalisasi disimpan dalam bentuk jpg di komputer Depo Arsip Suara Merdeka, sedangkan arsip fisiknya dijilid rapi dan disusun dalam rak-rak sesuai dengan urutan waktu penerbitannya.

\section{A. Pengkategorian dan Pengaksesan Arsip Surat Kabar}

Secara umum arsip surat 
kabar Suara Merdeka dapat dikategorikan ke dalam dua jenis. Jenis pertama berdasarkan frekuensi penggunaannya dapat dikategorikan ke dalam arsip inaktif karena frekuensi penggunaannya sudah menurun. Jenis kedua berdasarkan penggunaan langsung atau tidak langsung, maka d a a t p u 1 a dikategorikan dalam arsip statis karena arsip ini memiliki nilai guna kesejarahan, sehingga penggunaannya secara langsung sangat dibatasi. Dalam contoh kasus arsip statis ini, pengelola Depo Arsip melakukan pembatasan bagi para pengguna arsip. Mereka hanya bisa memegang arsip koran yang terbit tahun 1970 hingga sekarang. Kurang dari tahun tersebut, koran hanya bisa dilihat melalui monitor komputer. Tujuan dari pembatasan ini adalah untuk menjamin keselamatan fisik koran yang sudah mulai rapuh dan keefektifan pengguna arsip dalam mengakses arsip.

Bagi para pengguna yang menghendaki berita dalam kurun waktu 1950-1969, pengelola memberikan pelayanan pemotongan (cropping) berita yang sudah d i d i g i a 1 is a s i k a n menggunakan program olahan Photoshop. Hanya satu bagian berita saja yang bisa diberikan, bukan satu lembar koran sesuai dengan yang dibutuhkan pengguna. Hal ini digunakan untuk menghindari adanya penyalahgunaan arsip koran untuk kepentingan yang lain, seperti dikomersialisasikan. Depo Arsip Suara Merdeka memberikan berita yang diminta pengguna dalam bentuk file jpg, sehingga pengguna harus membawa flashdisk atau akan dikirim melalui email oleh pengelola. $\mathrm{P}$ e n g g u n a c u k p melampirkan identitas lengkap pada buku tamu atau 
menyerahkan surat izin dari lembaga yang diwakilinya untuk mengakses arsip koran.

Suara Merdeka sebagai perusahaan media massa swasta yang menjadi salah satu penyelenggara kearsipan memberikan akses pada arsip korannya secara terbuka. Pengguna hanya perlu datang dan memenuhi persyaratan umum sebagai pengakses arsip. Setiap arsip yang diambil oleh pengguna arsip tidak dipungut biaya sama sekali. Tujuan Suara Merdeka mendirikan Depo Arsip ini adalah selain untuk menunjang aktivitas pengolahan berita redaksi koran harian, juga untuk turut s e r t a m e n u n a n g pengembangan ilmu pengetahuan sesuai dengan jargon yang diamanatkan Budi Santoso pada bagian pendahuluan.
B. P e n c i pt a a $n$ a $n$ Penginputan Search Engine

Konsistensi Suara $\mathrm{M} \mathrm{e} \mathrm{r} \mathrm{d} \mathrm{e} \mathrm{k} \mathrm{a} \mathrm{y} \mathrm{a} \mathrm{ng}$ diimplementasikan oleh Depo Arsip Suara Merdeka dalam menciptakan pengelolaan arsip yang andal menemui jalannya ketika program mesin pencari berita (search engine) dikerjakan pada Januari 2015. Para pengelola depo arsip melihat realitas para pengguna arsip yang harus bersusah payah membaca berita satu demi satu. Kondisi ini sangat membuang-buang waktu, sehingga dibutuhkan terobosan akses arsip yang lebih mudah, cepat, dan tepat.

Program Search Engine ini dikerjakan oleh tim magang dari Jurusan Teknik Informatika Universitas Dian Nuswantoro (Udinus) selama tiga bulan'. Sebelum

\footnotetext{
${ }^{9}$ Teknik Informatika Universitas Dian Nuswantoro, "User Guide Pusat Data dan Analisa Suara Merdeka" (Semarang: Laporan Magang Teknik Informatika Universitas Dian Nuswantoro, 2015).
} 
program ini selesai, penulis ditugaskan oleh redaksi untuk membuatkan program pencari berita dan penyimpanan yang sederhana, mudah, dan cepat. Penulis berhasil menyusun program tersebut dalam bentuk Microsoft Excel.

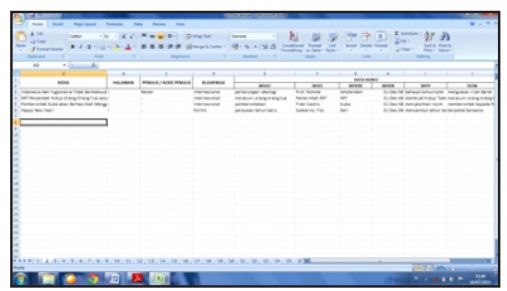

Gambar 1. program Microsoft Excel

Penyusunan sistem awal ini penulis sesuaikan dengan unsur-unsur utama yang melekat pada koran, yaitu judul, halaman, penulis/kode penulis, klasifikasi, dan enam unsur dasar dalam berita (apa, siapa, di mana, kapan, mengapa, dan bagaimana). Proses pengisian program awal dibantu oleh beberapa anak magang dari Sekolah Menengah Kejuruan (SMK). Proses terus berjalan hingga akhir tahun 2015 dan ditargetkan berhasil menginput semua berita pada dekade 1950-an.

Input pada program sederhana ini sebagai berikut. Satu file Microsoft Excel mewakili satu bulan, sehingga diatur menjadi 31 sheet yang sudah memiliki kolom yang sama. Para peserta magang SMK menginput data-data sesuai dengan kolom program tersebut. Selain siswa SMK, ada juga beberapa mahasiswa Diploma 3 Kearsipan Universitas Diponegoro ikut serta membantu dalam kegiatan pelatihan program search engine koran digital dan temu balik selama tiga bulan.

Setelah program Search Engine dari tim magang Udinus selesai, maka mulai dilakukan percobaan dengan memindahkan data-data yang telah disusun dari Microsoft Excel ke dalam Search Engine yang secara 
khusus dibedakan antara pengguna (user) dan penginput (admin).

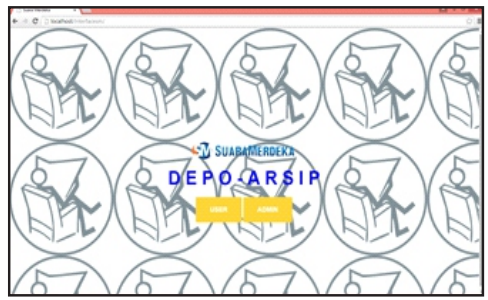

Gambar 2. tampak depan program Search Engine

Program ini juga satu demi satu dikopi dan dipindahkan. Semua proses pemindahan ini dikerjakan oleh peserta magang SMK setelah input data Microsoft Excelmereka selesai.

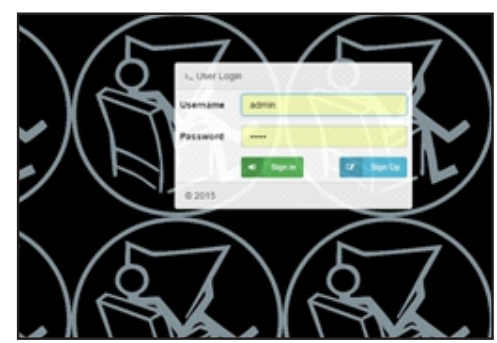

Gambar 3. admin Search Engine sebelum menginput data

Dengan demikian, dua proses penginputan terus dijalankan secara beriringan sampai sekarang.

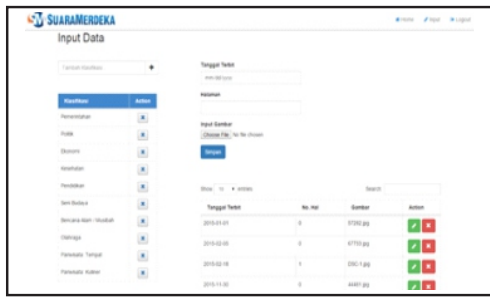

Gambar 4. bagian admin untuk input data

Hasil sementara yang dicapai adalah para pengguna bisa mengakses arsip jauh lebih cepat, khususnya pada berita antara 1950-1952 dan beberapa berita pada dekade 1950-an juga sudah diinput dalam Search Engine. Sementara data inputan yang belum masuk masih menunggu untuk dikerjakan segera.

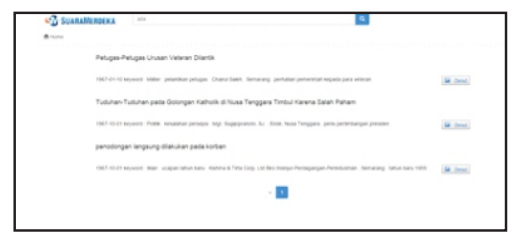

Gambar 5. user search engine yang siap digunakan

Perubahan pelayanan arsip dengan sistem semacam ini sangat 
membantu pengguna dalam mengakses arsip surat kabar yang terdiri dari ratusan berita yang ada di setiap edisinya.

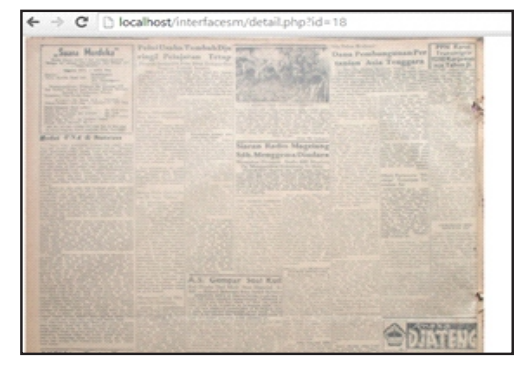

Gambar 6. arsip koran yang ditampilkan di user

Evolusi kecil berupa penyesuaian diri dengan kemajuan teknologi mungkin hanya beberapa media massa nasional yang menggunakannya. Lebih dari itu semua, Depo Arsip Suara Merdeka ingin memberikan pelayanan dan pengelolaan arsip yang tidak ketinggalan zaman, sehingga dapat berkembang dan mempertahankan eksistensinya sebagai "gudang harta karun pengetahuan".

\section{KESIMPULAN}

Dari berbagai uraian di atas dapat disimpulkan bahwa pengelolaan arsip yang andal oleh Depo Arsip Suara Merdeka bermuara pada pelaksanaan program Search Engine. Program ini mampu secara efektif dan efisen digunakan oleh para pengguna arsip koran Suara Merdeka. Suara Merdeka merupakan salah satu perusahaan swasta yang peduli terhadap pengembangan pengelolaan kearsipan sebagai sumber ilmu pengetahuan. Oleh sebab itu, pengelolaan kearsipan seyogyanya mengikuti perkembangan teknologi.

\section{SARAN}

Saran-saran yang dapat penulis sampaikan dalam karya tulis ilmiah ini adalah bagi pemerintah dan lembagalembaga kearsipan swasta untuk ikut serta aktif bertukar pikiran mengenai pengelolaan kearsipan sesuai dengan perkembangan teknologi informasi. Dengan adanya aktivitas tersebut 
diharapkan pelayanan arsip dalam berbagai bentuk dapat berjalan lebih efektif dan efisien. Selama ini yang khusus mengelola arsip surat kabar dengan lebih baik hanya beberapa instansi pemerintah dan segelintir perusahaan media massa.

\section{DAFTAR PUSTAKA}

Undang-Undang Republik Indonesia Nomor 43 Tahun 2009 Tentang Kearsipan

Bisri, Ahmad Zaini, "Dari Konsekstasi hingga Tema Politik Lokal: SM Jadi Jujugan Peneliti Mancanegara", Suara Merdeka, 11 Februari 2014.

Departemen Pendidikan dan Kebudayaan, Kamus Besar Bahasa Indonesia Edisi Kedua (Jakarta: Balai Pustaka, 1999).

Kartodirdjo, Sartono, Pemikiran dan Perkembangan Historiografi
Indonesia: Suatu Alternatif (Jakarta: PT Gramedia, 1982).

Murti, Yoshi Fajar Kresno, "Daur Ulang!: Kerja Arsip dan Pengarsipan Seni Budaya di Indonesia", dalam Farah Wardani dan Yoshi Fajar Kresno Murti (ed.), Arsipelago: Kerja Arsip dan Pengarsipan Seni Budaya di Indonesia Edisi 1 (Yogyakarta: Indonesian Visual Art Archive (IVAA), 2014).

Suryatmoko, Joned, “Arsip Bergerak: Mengarsipkan Seni Tradisi, Mengolah Interaksi”, dalam Farah Wardani dan Yoshi Fajar Kresno Murti (ed.), Arsipelago: Kerja Arsip dan Pengarsipan Seni Budaya di Indonesia Edisi 1 (Yogyakarta: Indonesian Visual Art Archive (IVAA), 2014).

Teknik Informatika Universitas Dian Nuswantoro, "User Guide Pusat Data dan Analisa Suara Merdeka" (Semarang: Laporan Magang Teknik Informatika Universitas Dian Nuswantoro, 2015). 